\title{
Teaching Competency for Business Educators: A Framework for Quality Assessment within Higher Education Institutions in ASEAN
}

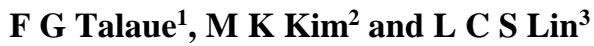 \\ ${ }^{1}$ Faculty of Humanities, Universitas Bina Nusantara, Jakarta, Indonesia \\ ${ }^{2,3}$ International Business Program, Universitas Bina Nusantara, Jakarta, Indonesia \\ ${ }^{1}$ fgtalaue@binus.edu, ${ }^{2 k i m . k u n g @ b i n u s . e d u, ~}{ }^{3} 11$ in@binus.edu
}

\begin{abstract}
This study aims to draft a teacher competency framework for business educators by taking into account the underpinnings of higher education regionalization in ASEAN. Employing a qualitative approach, the study generates data from interviews of respondents from ASEAN member countries such as Indonesia, Malaysia, the Philippines, Thailand, and Singapore. It is the overarching goal of the study to contribute to an ongoing discussion on regional integration. However, unlike other initiatives, it makes use of 'step-by-step' and 'bottom-up' approaches to the drafting of a competency framework for business education in the region, which may bear strong implications on quality assurance as expressed in quality assessment activities of higher education institutions offering business and allied programs.
\end{abstract}

Keywords: Competency, Business Educators, Education

\section{INTRODUCTION}

The growing need for an integrated higher education system in ASEAN, specifically for a shared policy on quality assurance among higher education institutions in the region [1] calls for a unified strategy to identify areas or touch points for quality assurance, which boils down to quality assessment in different milieus ranging from program to institutional settings, affecting policy-making at national and supranational levels.

Quality assessment in higher education such as within the ASEAN member countries bears strong implications on the achievement of mobility by actors in a higher education ecosystem, namely, students, lecturers, school administrators, and other stakeholders. The advent of regionalization and internationalization of higher education has spelled the need for a scrutiny of educational practices with the end goal of equalizing policies at program and institutional levels within supranational domains. It is an acknowledged fact, however, that the mobility of academics within permeable educational systems "remains largely unexamined" [2].

In order to address quality issues on higher education in the region, regional bodies have been created to oversee the implementation of quality assessment processes. For example, the ASEAN University Network (AUN) has made significant efforts since 1995 to assess program offerings by member universities from all the ten member states of ASEAN. In 2012, AUN 
has expanded to welcome within its fold three other countries, namely, China, Korea, and Japan to widen educational cooperation under the ASEAN+3 UNet initiative [3], [4].

Within the QA framework of AUN at the program level, assessors look into areas such as teaching and learning processes, including expected outcomes and student, academic, and support staff quality. This assessment framework is adopted by all AUN member universities as they undergo the exercise of quality assessment. However, it appears that a single, unitary framework is applied to all programs disregarding the nuances and unique characteristics of certain programs.

This paper, therefore, argues that quality assessment must be specific in order to meet the unique character of certain programs, resulting in a more detailed and objective assessment of quality. Specifically, this study would like to propose a competency framework for business educators, taking into consideration the ASEAN business education landscape. Overall, the study hopes to contribute to the achievement of the goals of regional cooperation in the field of education as formalized at the Cha-am HuaHin Declaration which underscores the important "role of education in building the ASEAN community" [5].

\section{LITERATURE REVIEW}

\subsection{Regionalization of Higher Education}

Knight cited the definition of regionalization in higher education as the "process of building closer collaboration and alignment among higher education actors and systems within a defined area or framework called a region". [6] Regionalization, therefore, is a way through which the internalization of education and its tenets find expression within a regional bloc which is determined to strengthen social, economic, and political ties among proximate countries. The ASEAN community, which has been touted as one of the more successful supra-governmental organizations that aim to foster regional security and stability within member countries, is an exemplar of this cooperation. To effect tangible outputs in identified areas such as in education, regional bodies have been established. The ASEAN University Network and the Southeast Asian Ministers of Education Organization (SEAMEO) are just two of the few regional instruments that initiate QA systems and programs, which promote the freer movement of students, staff, and curricula within the ASEAN playing field. These regional bodies are concerned with setting up standards with which universities may measure themselves up against in the common pursuit of quality. However, the AUN, for example, has drawn criticism for taking an 'elitist' stance on educational integration. Most of the AUN member universities are top government universities in the region, forming the circle of 30 elite universities. [7] More recently, five universities from China, three from Korea, and ten from Japan have been added to the list (ASEAN Unet Member Universities, n.d.). Aside from the issue of very weak coverage, it can also be pointed out that ASEAN universities are as diverse as the region itself, making absolute integration a daunting task.

Today, the ten member countries of ASEAN are at different stages of economic development. This disparity is seen as a determinant of the subsequent development of differentiated education systems in the region. [8] As such, it can pose a challenge for comparing or harmonizing educational practices in the context of regionalization not only within the ASEAN region but within the bigger playing field of Asia. As Hawkins argued, the "regionalization and harmonization of higher education in Asia (is) easier said than done". To complicate the issue, the push for certain economic agendas may wield a strong influence on how quality assurance in higher education is carried out as an aspect of regionalization [9]. 
This paper asserts, however, that working towards integration at a regional level requires different stakeholders to come together to implement a framework for the harmonization of educational practices at a micro-level, following a bottom-up approach which should involve as many higher educational institutions as possible. This idea is in line with a "step-by-step approach" to the carrying out of regional activities instead of an "overarching regional framework". [7] Sporadic bottom-up approaches, however, may not work very well for a notion of harmonized educational practices, and so mobilizing institutions that are readily identifiable under a common objective, that is, integration, can work well for a region as diverse as ASEAN. Although regionalization efforts within the Southeast Asian region have gained more attention as compared to the bigger Asia Pacific Quality Assurance Network solidified initiatives cutting across more universities in ASEAN need to be put in place. [6]

In other parts of the world, the Bologna Process has gained ground for establishing a commonality of practices in the European higher education sphere, as it laid out the framework for the European Higher Education Area [10] which has become a model for higher education efforts elsewhere. [6] In fact, an inter-regional cooperation effort between the European and ASEAN higher education stakeholders through SHARE, the European Union Support to Higher Education in the ASEAN Region, is currently in effect in order to help the ASEAN region harmonize "regional higher education by sharing European expertise". [1] A similar inter-regional cooperation between the European Union and Southeast Asian higher education institutions is also being implemented through the project ACCESS funded by the European Commission [11] Despite these cooperation efforts, however, it has been noted that Southeast Asia "does not have as comprehensive and integrated a system of academic exchange" [12] as the European Higher Education Area.

Similar efforts aimed at regionalizing higher education practices are happening in African states and in Latin America and the Caribbean. In the rest of Asia, Knight reported about PanAsia initiatives to cover at least five regional blocs that work on integration activities which are nonetheless overshadowed by ASEAN regionalization efforts.

\subsection{Internationalization, Quality Assurance and Teaching Competency: Frameworks to Practices}

Knight(as cited in [13]) described four approaches by which higher educational institutions can pursue the internalization agenda as follows:

Table 1.Approaches to internationalization.

\begin{tabular}{ll}
\hline Approach & Description \\
\hline \multirow{4}{*}{ Activity } & Categories or types of activities used to describe internalization \\
& such as curriculum, student/faculty exchanges, technical \\
& assistance, international students \\
\hline \multirow{3}{*}{ Competency } & Development of new skills, knowledge, attitudes and values in \\
& students, faculty and staff. As the emphasis on outcomes of \\
& education grows there is increasing interest in identifying and \\
& defining global/international competencies \\
\hline Ethos & Emphasis is on creating a culture or climate on campus which \\
& promotes and supports international/intercultural initiatives \\
\hline \multirow{2}{*}{ Process } & Integration or infusion of an international or intercultural \\
& dimension into teaching, research and service through a \\
\hline
\end{tabular}


combination of a wide range of activities, policies and procedures.

Competency as an approach to internationalization focuses on the skill sets of students, faculty, and staff. Framing the skill sets that academic staff need to possess has a strong implication on quality assurance as expressed in program and/or institutional level quality assessments. Knight observed that " $[\mathrm{t}]$ he preoccupation with competencies is interesting in that research and discourse is now taking place on defining competencies, sometimes called international or global or transnational competencies"[13].

As seen in the table, however, competency is but one of the four approaches to internalization. In the same vein, the European Commission on Education and Training has reported that a framework of teacher competency "is but one of a number of instruments that can be used to support teachers' professional development, and to promote quality in education. Furthermore, the commission asserted that a framework of competency should be a result of an agreement among stakeholders as to what teachers are for or what education should be, considering, among other things, national or international contexts and issues.

The ASEAN University Network-Quality Assurance (AUN-QA) Model for Program Level has identified Academic Staff Quality as one of the 15 areas of focus for assessment. The AUN-QA framework for Academic Staff Quality "encompasses qualification, subject matter expertise, experience, teaching skills, and professional ethics"

The following table specifies the AUN-QA Checklist for Academic Quality Staff. [3]

Table 2.AUN-QA Criterion 6 - Checklist.

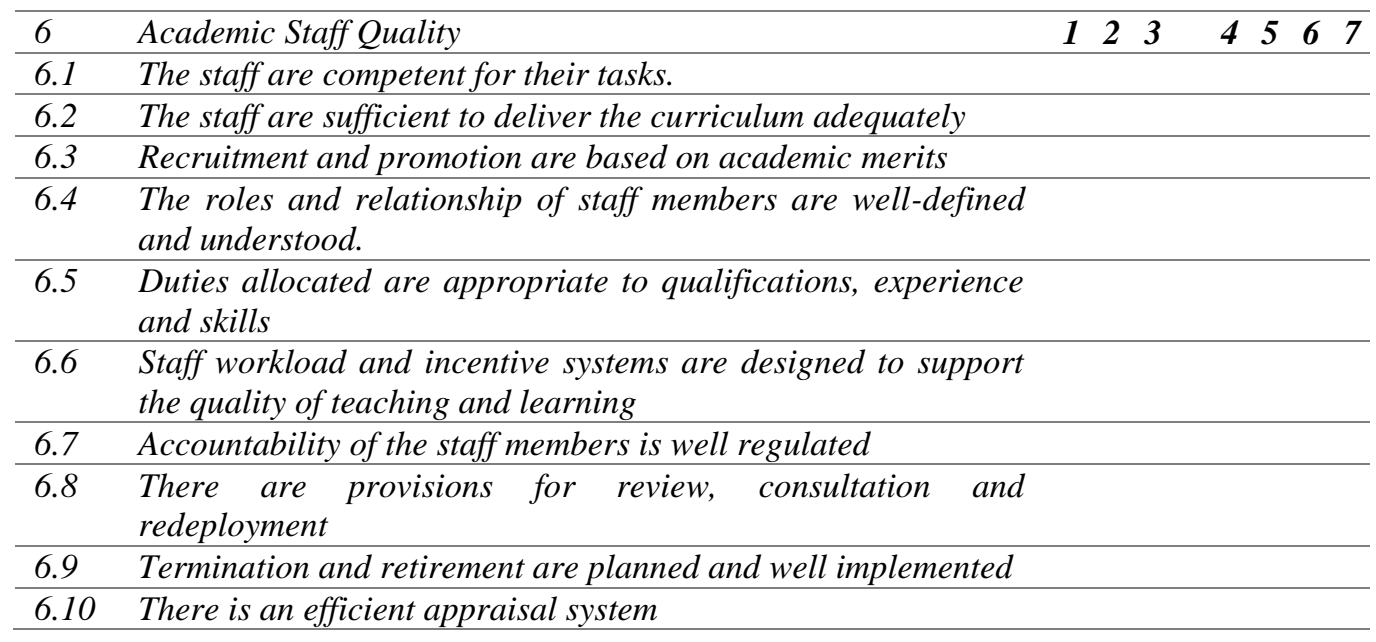

As seen from the table above, the checklist for staff quality directly relates with qualifications, experience, subject mastery, and ethos as reflected in the quality framework for staff of the AUN-QA. However, the way the items are articulated gives the impression of the power dynamics between school administrators and teachers as employees. This implies a top down approach to the drafting of a competency framework. It can be assumed that teaching staff may not have been directly consulted in the drafting of the AUN-QA Criterion 6. The European Commission has argued that if a teacher competency framework were to become effective in establishing quality, teachers must be involved in the drafting of such a framework. In this way, they are able to feel a sense of ownership. The process of quality 
assurance may well be readily acceptable "where there is already a culture of "teacher selfevaluation; teachers' reflection on their own work, and teacher professionalism".[14]

\subsection{Competence}

The ASEAN member countries through the ASEAN Qualifications Reference Framework (AQRF) have spelled out competence as follows:

Competence is an ability that extends beyond the possession of knowledge and skills. It includes:

1. cognitive competence involving the use of theory and concepts, as well as informal tacit knowledge gained experientially;

2. functional competence (skills or know-how), those things that a person should be able to do when they work in a given area;

3. personal competence involving knowing how to conduct oneself in a specific situation; and,

4. ethical competence involving the possession of certain personal and professional values

Defining teacher competence is imperative to quality assessment. In fact, academic staff quality is almost always a major criterion included in assessment processes across all levels of education. For instance, the European Union member countries through the European Commission have emphasized that a teacher competency framework is important for the following reasons: [15].

- defining the learning outcomes of initial teacher education programs

- defining criteria for recruitment and selection to teaching posts

- assessing teachers' needs for in-service training, and

- arranging the provision of professional learning opportunities so that teachers continue to develop their competences throughout their whole career

Part of the difficulty of QA assessments of member countries in regional blocs around the world is the fact that there may be big differences in the levels of development of their educational systems and how 'the concept of teacher competences may resonate differently in different national contexts. [13] Nonetheless, it is the overall goal of QA systems to ensure that QA assessments and accreditation processes in general allow for comparisons of educational practices which could lead to "harmonizing regional educational processes" [1]

\section{METHOD}

In order to map out a competency framework for business education that capitalizes on a bottom up approach, semi-structured interviews were conducted with thirteen lecturers who teach business in the undergraduate level in countries such as Indonesia, Singapore, the Philippines, Malaysia, and Thailand. Initially, twenty respondents were targeted to participate in the study, but the researchers deemed that the data collected has reached a saturation point following the results of a recursive coding of data. A discriminant sampling strategy [16] which meant that succeeding interviewee profiles were different from previous interview profiles, also ensured saturation as repetitive substantive themes or categories emerged.

All the thirteen interviews revolved around the following research question: 
What skill sets should educators have to deliver business education par excellence against the backdrop of a regional and/or international education?

An overall emic approach was employed in this qualitative study. As such the participants' worldview was largely the basis of the analysis. The recurrent themes that were generated were primarily derived from the perspectives of the respondents. The semi-structured interviews with all the thirteen respondents started with the open-ended question, 'Who is the ideal business educator?' Follow up questions were asked as the interviews ensued, revolving around the major ideas or concepts that the respondents discussed.

\section{FINDING and DISCUSSION}

\subsection{Findings}

The table below presents the major components of a competency framework for business education, following a thorough analysis of the interview transcripts generated by the study. The following are aspects of competence for business educators, resulting from an iteration of the research data: academic preparation, professional experience, personal effectiveness, cultural sensitivity, pedagogical skills, and meta-cognitive skills.

Table 3. Competency Framework for Business Educators.

\begin{tabular}{|c|c|}
\hline Competence Area & Description \\
\hline Academic Preparation & $\begin{array}{l}\text { This competence area relates to the educational } \\
\text { background and qualifications of the business educator. }\end{array}$ \\
\hline Professional Experience & $\begin{array}{l}\text { This competence area refers to skills acquired, } \\
\text { reinforced, or developed outside years of formal studies to } \\
\text { include industry and/or entrepreneurial experiences. }\end{array}$ \\
\hline Personal Effectiveness & $\begin{array}{l}\text { This competence area covers personal qualities, including } \\
\text { values, attitudes, and beliefs that contribute to overall } \\
\text { teaching effectiveness. }\end{array}$ \\
\hline Cultural Sensitivity & $\begin{array}{l}\text { This competence area relates to the ability of the business } \\
\text { educator to work within existing local contexts and be able } \\
\text { to recognize diversity in students and the community as a } \\
\text { whole. }\end{array}$ \\
\hline Pedagogical Skills & $\begin{array}{l}\text { This competence area refers to the ability of the business } \\
\text { educator to employ appropriate teaching-learning methods } \\
\text { and approaches in his or her own practice. }\end{array}$ \\
\hline Meta-cognitive Skills & $\begin{array}{l}\text { This competence area mainly deals with the ability of the } \\
\text { business lecturer to think about his own professional practice } \\
\text { and reflect upon it for continual improvement as an educator. }\end{array}$ \\
\hline
\end{tabular}

\subsubsection{Academic Preparation}

As an aspect of competence, academic preparation, including appropriate educational qualifications, which as set up by most educational institutions should be a master's degree, is considered by the respondents as ideal. Lecturers should also have adequate levels of knowledge of related disciplines, which as labelled by one respondent refers to 'crossfunctional' knowledge. Finally, lecturers must be able to acquire research skills during their 
years of academic preparation which they could use to carry out actual research to inform their teaching practice. As one respondent reported, the university she works for implements 'research-led teaching' or teaching that is driven by research output by lecturers themselves. Table 2 sums up this aspect of competence as found below:

Table 4.Standards and Indicators of Academic Preparation.

\begin{tabular}{ll}
\hline \multicolumn{1}{c}{ Standards } & \multicolumn{1}{c}{ Indicators } \\
\hline Appropriate educational & Have at least a master's degree in \\
qualifications & a business or relevant field. \\
Cross-functional & Able to teach related disciplines \\
knowledge & within business and allied courses \\
Research capability & Carry out theoretical and/or \\
& empirical research. \\
\hline
\end{tabular}

\subsubsection{Professional Experience}

Industry experience is important in that the business lecturer should be able to bring into the classroom his or her experience of the real world. In one interview, a respondent from Indonesia said that industry and educational collaborations should begin with the notion that such collaborations are beneficial for both parties. He stressed that, at times, industries tend to give away more of themselves to the education sector. He believes that there is a lack of reciprocity in some of these collaborations. It is in this light that lecturers should have firsthand industry experience to provide real world business insights while the education system is findings ways to achieve mutuality between education and industry collaborations. In addition, in order to be abreast with developments in their fields of expertise, business lecturers should strive to be a part of professional organizations. The table below presents a summary of professional experience as a specific competence area.

Table 5.Standards and Indicators of Professional Experience.

\begin{tabular}{ll}
\hline \multicolumn{1}{c}{ Standards } & \multicolumn{1}{c}{ Indicators } \\
\hline Industry experience & $\begin{array}{l}\text { Have ample exposure to industry and real } \\
\text { business practices. } \\
\text { Be a member of professional organizations, } \\
\text { Membership to professional organizations }\end{array}$ \\
\hline
\end{tabular}

\subsubsection{Personal Effectiveness}

Personal effectiveness refers to the personal qualities lecturers should have as they deal with students in and out of the classroom and with colleagues. As presented in Table 4 below, this competence area, as described by the respondents of the study involves the ability to network, collaborate with colleagues and other professionals in the field, and motivate students. The lecturer's communicative ability is considered important in this respect. 
Table 6.Standards and Indicators of Personal Effectiveness.

\begin{tabular}{cl}
\hline \multicolumn{1}{c}{ Standards } & \multicolumn{1}{c}{ Indicators } \\
\hline $\begin{array}{c}\text { Networking and } \\
\text { collaboration skills }\end{array}$ & Able to do personal and professional networking. \\
& Motivate students. \\
& Maintain collegial relationships with fellow lecturers. \\
Personal qualities & Communicate well with students and peers on personal and \\
& professional levels.
\end{tabular}

\subsubsection{Cultural Sensitivity}

A recurrent theme found in the study is the consideration of a lecturer's ability to navigate through different cultural milieus. Five respondents of the study expounded on the idea that lecturers should be aware of business contexts within their individual educational spheres. On the one hand, being in touch with local business environments, as asserted by a respondent, allows for curriculum relevance that is rooted in local industry practices. On the other hand, being sensitive to cultural differences is also helpful for lecturers to understand diversity in the classroom.

Table 7.Standards and Indicators of Cultural Sensitivity.

\begin{tabular}{ll}
\hline \multicolumn{1}{c}{ Standards } & \multicolumn{1}{c}{ Indicators } \\
\hline $\begin{array}{l}\text { Cross-cultural communication } \\
\text { and understanding }\end{array}$ & $\begin{array}{l}\text { Adapt to different communication styles of students and } \\
\text { peers from different cultural backgrounds. } \\
\text { Integrate local business practices and concepts in the } \\
\text { syllabus } \\
\text { Knowledge of local business } \\
\text { Wontexts and practices }\end{array}$ \\
$\begin{array}{l}\text { Work with the local business community to bridge the gap } \\
\text { between theory and practice. }\end{array}$
\end{tabular}

\subsubsection{Pedagogical Skills}

The ability to transfer knowledge and skills to students is also another major theme that has been expounded by the respondents. They believe that competent lecturers should have the ability to design a curriculum that sutures critical thinking, leadership, and communication skills as part of a subset of soft skills development in students, while recognizing the importance of understanding overall educational objectives and how they are assessed to measure student learning.

Also, the respondents believe that an ideal business educator should be able to implement varied forms and styles of teaching delivery as anchored on different pedagogical approaches relevant to the needs of business education. For example, business lecturers need to know how to employ case teaching techniques and, at the same time, understand how educational technologies may work in a set up like the flipped classroom. In addition, they should be able to write modules as and when needed and be able to tailor their lesson plans to the specific needs of their students while keeping in mind the overall goals of a course. 
Finally, the business lecturer should be able to employ language and communicative techniques in the classroom to affect teaching and learning within the confines of a wellmanaged classroom.

Table 8.Standards and Indicators of Pedagogical Skills.

\begin{tabular}{|c|c|}
\hline Standards & Indicators \\
\hline $\begin{array}{l}\text { Curriculum } \\
\text { design }\end{array}$ & $\begin{array}{l}\text { Able to design a course syllabus, including the ability to integrate soft or } \\
\text { life skills in the curriculum, such as critical thinking, leadership, } \\
\text { communication, etc. } \\
\text { Understand overall course and program objectives } \\
\text { Recognize the importance of theory and practice in the curriculum }\end{array}$ \\
\hline $\begin{array}{l}\text { Curriculum } \\
\text { implementation }\end{array}$ & $\begin{array}{l}\text { Able to transfer knowledge and skills through effective classroom } \\
\text { language } \\
\text { Integrate research output into teaching (research-led teaching) } \\
\text { Manage the classroom effectively. } \\
\text { Deliver lessons using appropriate teaching approaches, e.g., case study } \\
\text { teaching, flipped learning. } \\
\text { Assess student learning } \\
\text { Prepare teaching materials as appropriate, i.e., modules, lesson plans. }\end{array}$ \\
\hline
\end{tabular}

\subsubsection{Meta-Cognitive Skills}

Most of the respondents also believe that ideal business lecturers are reflective or mindful of their own practices. Reflecting on one's overall philosophical outlook relating to educational perspectives, such as the concept of lifelong learning, may affect how one designs and delivers lessons in the classroom. As one respondent put it, the educator's ability to "deeply understand the concept of education" may be seen in his or her own day-to-day approach in dealing with his students and delivering the lesson of the day.

Table 9.Standards and Indicators of Meta-Cognitive Skills.

\begin{tabular}{lll}
\hline \multicolumn{2}{c}{ Standards } & \multicolumn{1}{c}{ Indicators } \\
\hline $\begin{array}{l}\text { Reflect } \\
\text { practices }\end{array}$ & upon teaching & $\begin{array}{l}\text { Able to reflect on their own teaching practices in } \\
\text { terms of a) lifelong learning b) holistic education c) } \\
\text { the teacher as facilitator d) internationalism }\end{array}$ \\
\hline
\end{tabular}

\subsection{Discussion}

The agreed upon nomenclature for a regional competency framework for quality assurance and recognition of certification systems in the ASEAN region specifically lists cognitive, functional, personal, and ethical competences. [15] It is argued that the specific aspects of competence as established in this study may fit well into the recognized nomenclature. However, what this study has found out is that there are specific delineations of competences or skill sets which lecturers consider important considering a specific educational landscape such as business education in ASEAN. 


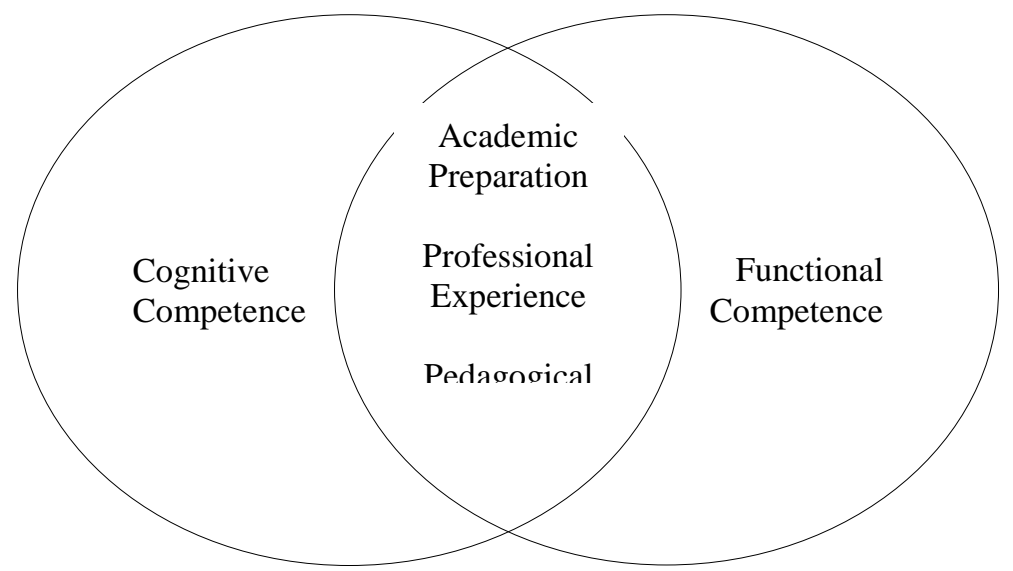

Figure 1. How Academic Preparation, Professional Experience, and Pedagogical Skills Fit into Cognitive and Functional Skills.

The diagram above illustrates how the three competence areas fit into the existing framework of competence for quality assurance and certification systems across ASEAN as ratified by the member countries.[15] Academic preparation, professional experience, and pedagogical skills straddle between cognitive and functional competences. It is important, however, to see further delineations in order to fully highlight specific skills that may be special to certain fields of study. The three competence areas as cited above may be used across all fields of teaching, but the study has established that there are specific competences that may be considered paramount to business education and other fields of study within a regional context as found in the succeeding diagram.

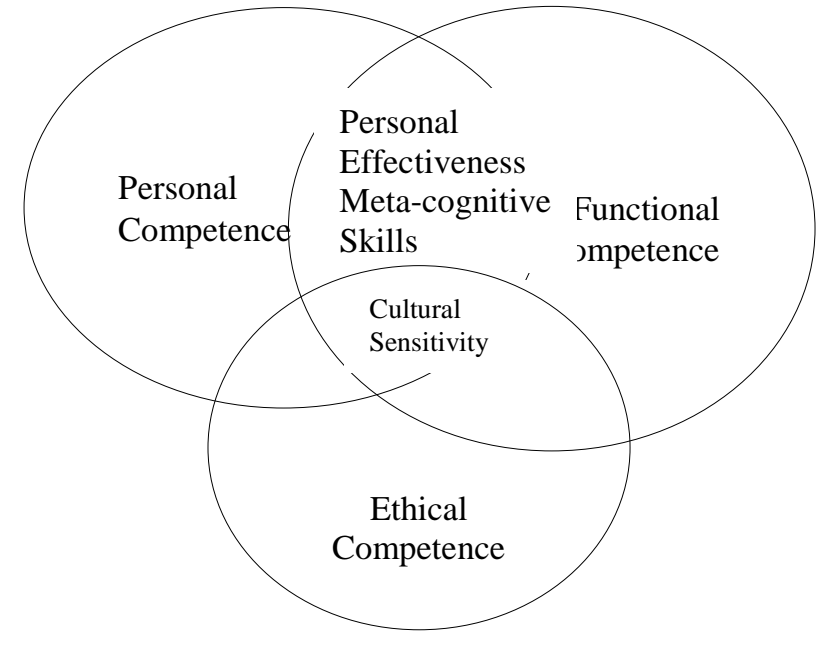


Figure 2. How Personal Effectiveness, Meta-cognitive Skills, and Cultural Sensitivity Fit into Personal and FunctionalCompetences.

As seen in Figure 2, cultural sensitivity is a competence area that may be considered relevant for a business education context that operates within the remit of internationalization. Baker as cited in [17] observed that cross-cultural and intercultural awareness has gained relevance in education through the years, but little has been done to address it in actual educational practices. The respondents' recognition of the relevance of cultural sensitivity is a result of their acknowledgment of the fact that there is an increasing trend of student and staff mobility across transnational borders. On the one hand, an awareness of cultural differences in the classroom may be helpful for lecturers to understand, for example, how students coming from different cultural backgrounds communicate or see power relations in the classroom. On the other hand, sensitivity to cultural differences may also provide lecturers the impetus to take up or integrate local business practices in the curriculum.

Meta-cognitive skills are also an aspect of competence which the respondents thought as relevant to their teaching practice. The ability to reflect upon the philosophical underpinnings of why and how one teaches may be an indication of professional maturity and predict how a business educator may continuously grow in the profession. In the field of teacher education, however, Cornford argued "there is no empirical evidence that clearly establishes that reflective teaching approaches have resulted in superior teaching...".[18] The respondents of the study, however, believe that thinking about educational conceptions, such as valuing lifelong learning and having the ability to deeply understand what education is and being able to clearly reflect this understanding in their own practice are integral to successful teaching.

This paper has also elaborated the AUN-QA Checklist for Academic Quality of Staff. Such an elaboration is important for academic institutions and accrediting bodies to better evaluate teaching competence for business education. All the six competence areas that this study has developed relate to items on the AUN-QA Checklist such as the following: "The staff are competent for their tasks; Recruitment and promotion are based on academic merits; The roles and relationship of staff members are well-defined and understood; Duties allocated are appropriate to qualifications, experience and skills". [18] It must be said, however, that there are certain aspects in the quality checklist which have not been addressed such as the following: "There are provisions for review, consultation and redeployment; Termination and retirement are planned and well implemented; There is an efficient appraisal system; Staff workload and incentive systems are designed to support the quality of teaching and learning; and Accountability of the staff members is well regulated". [18]

\section{CONCLUSION}

The overarching goal of this study is to map out a competency framework for business education within the pretext of a growing need for a more efficient higher education regionalization effort with special emphasis on business education in the ASEAN region. The exponential growth of higher education in the Asian continent, including Southeast Asia, [19] has brought forth challenges in the higher education sector, including but not limited to "shortages of qualified instructional staff (and) a need to improve instructional quality".

In order to address these problems afflicting much of the higher education sector in this part of the world, quality assurance frameworks have been put in place. A major component or criterion of higher education quality assurance policies relates to the quality of the academic 
staff of higher education institutions. For example, ASEAN member countries such as Cambodia, Indonesia, Malaysia, and Thailand [20] have laid out quality assurance frameworks that give importance to the quality of teachers as pivotal in achieving the educational goals of these countries.

While it is true that certain descriptors of quality have been assigned to higher education academic staff as seen in existing quality assurance frameworks, the study found out that these are too generic and may not fully apply to business education in the ASEAN region. It is within this premise that the study has identified aspects of business education competences as follows: academic preparation, professional experience, personal effectiveness, cultural sensitivity, pedagogical skills, and meta-cognitive skills.

The study recommends that a further investigation should be done to cover all other possible cohorts of respondents such as students and industry practitioners across a majority, if not all, countries in the ASEAN region. A combination of qualitative and quantitative approaches may be used to extend the study to come up with a more definitive framework for teaching business amid the increasing mobility of educators in ASEAN higher education.

\section{REFERENCES}

[1] F. Niedermeier and P. Pohlenz, State of Play and Development Needs: Higher Education Quality Assurance in The ASEAN Region. Jakarta: DAAD, 2016.

[2] T. Kim and W. Locke, "Transnational Academic Mobility and The Academic Profession," London, 2010.

[3] U. N. S. ASEAN, Guide to AUN Quality Assessment At Programme Level. Bangkok: AUN Secretariat, 2011.

[4] Y. Rui, "Internationalization, Regionalization, and Soft Power: China's Relations with ASEAN Member Countries in Higher Education," Front. Educ. China, vol. 7, no. 14, pp. 486-507, 2012.

[5] S. ASEAN, "ASEAN State of Education Report 2013," ASEAN Secretariat, Jakarta, 2013.

[6] J. Knight, "A Conceptual Framework for the Regionalization of Higher Education: Application to Asia," in Higher Education Regionalization in Asia Pacific, J. N. et al Hawkins, Ed. New York, USA: Palgrave Macmillan US, 2012, pp. 17-35.

[7] A. T. Nguyen, "The Role of Regional Organizations in East Asian Regional Cooperation and Integration in the Field of Higher Education," Asian Reg. Integr. Rev., vol. 1, pp. 69-82, 2009.

[8] T. Songkaeo and L. Yeong, "Defining Higher Education Issues and Challenges inSoutheast Asia/ASEAN Within The International Context," The Head Foundation, 2016. [Online]. Available: http://www.headfoundation.org/papers/2016_Defining_Higher_Education_Issues_and _Challenges_in_Southeast_AsiaASEAN_within_the_International_Context.pdf .

[9] J. Hawkins, "Regionalization and Harmonization of Higher Education in Asia: Easier Said Than Done," Asian Educ. Dev. Stud., vol. 1, no. 1, pp. 96-108, 2012.

[10] S. Mihayara, Regional Quality Assurance System for Higher Education in Southeast AsiaQuality Assurance in LIS Education: An International and Comparative StudyEd M Miwa and S Mihayarapp. New York: Springer Science, 2015.

[11] Erasmus Mundus Programme, "Project Access: Strategies to Strengthen Collaboration inHigher Education Between Europe and South East Asia," Asean University Network, 2010 .

[Online].

Available: 
http://www.aunsec.org/Section8/8.2.6/8.2.6ACCESS(fordownload).pdf.

[12] D. Lek, "Cross Border Higher Education in ASEAN: Structure, Policies, Development and Integration," ASEAN-Canada Res. Partnersh. Work. Pap. Ser., no. 4, pp. 1-26, 2014.

[13] J. Knight, "Internationalization of Higher Education," Qual. Internalization High. Educ. Wit J Kn., pp. 13-28, 1999.

[14] European Commission Education and Training, "Supporting Teacher Competence Development for Better Learning Outcomes," Eur. Comm. Educ. Train., 2013.

[15] A. Bateman, "ASEAN : Guiding Principles for Quality Assurance andRecognition of Competency Certification Systems," ASEAN, 2016. [Online]. Available: http://asean.org/storage/2012/05/ASEAN-\%0AGuiding-Principles-for-Quality-

Assurance-and-Recognition-of-Competency-Certification-\%0ASystems1.pdf\%0A.

[16] J. Creswell, Qualitative Inquiry \& Research Design: Choosing Among Five Approaches. Los Angeles: SAGE Publications, 2013.

[17] C. Tarchi and A. Surian, "Developing Cross-Cultural Awareness in Higher Education Through The Use of Video-Logs Focusing On Critical Incidents Open Spaces for Interactions and Learning DiversitiesEd A Surianpp," in Open Spaces for Interactions and Learning DiversitiesEd A Surianpp, Rotterdam: Sense Publishers, 2016, pp. 205215.

[18] I. Cornford, "Reflective Teaching: Empirical Research Findings and Some Implications forTeacher Education," J. Vocat. Educ. Train., vol. 54, no. 2, pp. 219 236, 2002.

[19] Asian Development Bank, Education Across Asia: An Overview of Issues and Strategies. Philippines: Asian Development Bank, 2011.

[20] Asian Development Bank, Private Higher Education Across Asia: ExpandingAccess, Searching for Quality. Philippines: Asian Development Bank, 2012. 